\title{
INÍCIO
}

\section{Past, present and future of geochemical input-output budgets}

\author{
F. A. L. Pacheco \\ C. H. Van der Weijden
}

Department of Geology, Trás-os-Montes e Alto Douro University, Vila Real, Portugal

Department of Gcochemistry, Institute of Earth Scienecs, Utrecht University, Utrecht, Netherlands
Geochemical mole-balance studies (also known as input-output budgcts) invoke a simple conservationof-mass principle, the principle that 'some of it plus the rest of it equals all of it'. Quantitative molcbalance modelling was introduced to geochemical literature by Garrels and MacKenzie (1967) in a study referred to in many textbooks; they presented a classical analysis of the natural processes responsible for the composition of springs and groundwater in a pristine area (Sierra Nevada, USA), which became known as the 'balance-sheet' method, and has becn employed by numerous other workers. In the present paper we present a brief overview of mole-balance models (and associated cnvironments) that have becn used in the recent past, that are in use in the present, and which are under development for application in the near future.

In studies of small and pristine watersheds, where most stream flow is fed by subsurface water percolating the soil and saprolite, the composition of springs and streams is essentially influenced by the atmospheric input plus the chemical and biological reactions occurring within the weathering profile (Taylor and Velbel, 1991). The budget for the watershed may be described by the equation:

$$
\left[Y_{i}\right](\text { (inal })=\left[Y_{i}\right](\text { initial })+\sum_{k=1}^{1} r_{j k}\left[P_{k}\right]
$$

where $\mathrm{i}-1, \ldots, \mathrm{n}$.

In Equation 1, $\left[\mathrm{Y}_{\mathrm{i}}\right]\left(\right.$ final) and $\left[\mathrm{Y}_{\mathrm{i}}\right]($ initial) are the molar concentrations of the ith dissolved component in spring/stream and rain water, $\left[\mathrm{P}_{\mathrm{k}}\right]$ is the mole transfer of the kth reactant phase, and $r_{i k}$ is the ratio between the stoichiometric coefficients of component $i$ and phase $k$ in the reaction of phase $k ; n$ and $p$ are the number of dissolved components in the chemical system and the number of reactant pliases, respectively.

In studies of large and pristine hydrographic basins, where the interest in weathering and base cation fluxes becomes more oriented towards the analysis of the chemical evolution of water along the flow paths (Parkhurst, 1997), models relate the chemistry of an aqueous solution (final solution) to a set of mixing fractions of initial solutions and to a set of mole transfers of minerals and gases. In this case the formulation may be expressed by the equation:

$$
\left[\mathrm{Y}_{\mathrm{i}}(\text { (final })=\sum_{\mathrm{j}-1}^{\mathrm{m}} \alpha_{\mathrm{i}}\left[\mathrm{Y}_{\mathrm{i}}\right](\text { initial })+\sum_{\mathrm{k}=1}^{\mathrm{p}} \mathrm{r}_{\mathrm{ik}}\left[\mathrm{P}_{\mathrm{k}}\right]\right.
$$

where $\left[\mathrm{Y}_{\mathrm{ij}}\right]$ (initial) is the molar concentration of the ith dissolved component in each of the $\mathrm{m}$ initial solutions and $\alpha_{\mathrm{j}}$ is the mixing fraction of solution $\mathrm{j}$.

Geochemical inpul-output budgets can handle mass balances including hydrolysis of silicates, dissolution of carbonates/evaporites, ion exchange, botanical uptake/release of base cations or redox reactions. isotope balances and simple mixing of endmember walers. In the vast majority of cases, models are calculated by exact methods which involve the solution of a set of $\mathrm{n}$ cquations in $\mathrm{n}$ unknowns. but the most recent methods (Parkhurst, 1997) use approximation techniques such as linear programming in order to turn around the problem of solving sets with more unknowns than equations. Implicit in all these approaches is the assumption that the final aqueous solution did indeed evolve from the initial solutions by reaction with the proposed phases, or in other words, that there is a correspondence between the chemistry of the final aqueous solution and the chemistry of the end-member solutions plus the stoichiometric relations between dissolved components and reaction phases, and vice-versa. In case this assumption is not fully guaranteed, the results obtained with the budgeting will surely be as unpredictable as unrealistic.

Pacheco and Van der Weijden (1996), working in an inhabited arca with intensive agriculture (the Fundão granitoid plutonite, central Portugal), developed an approach (the Silica-Bicarbonate - SiB algorithm) to deal with situations in which a portion of the final concentration of a chemical element is associated with a set of processes whose stoichiometry is hardly predictable in advance, for example the contribution to groundwater chemistry of sources 
TABLE 1. Geochemical mole-balance models, associated environments and mathematical approaches

\begin{tabular}{|c|c|c|}
\hline \multirow[b]{2}{*}{ 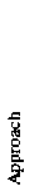 } & $\begin{array}{c}\text { Number of unknowns ( } \mathrm{n} \text { ) less or equal than } \\
\text { number of equations ( } \mathrm{m})\end{array}$ & $\mathrm{n}>\mathrm{m}$ \\
\hline & $\begin{array}{c}\text { Exact methods } \\
\text { ( solution of sets of linear equations) }\end{array}$ & $\begin{array}{l}\text { Approximation techniques } \\
\text { (linear and non-linear programming) }\end{array}$ \\
\hline & & $\begin{array}{l}\text { Budgets of large hydrographic basins in areas of dominant } \\
\text { anthropogenic influence } \\
{\left[\mathrm{Y}_{\mathrm{i}}\right](\text { final })=\sum_{\mathrm{j}=1}^{\mathrm{m}} \alpha_{\mathrm{j}}\left[\mathrm{Y}_{\mathrm{ij}}\right] \text { (initial) }+\sum_{\mathrm{k}=1}^{\mathrm{n}} \mathrm{r}_{\mathrm{ik}}\left[\mathrm{P}_{\mathrm{k}}\right]+\left[\mathrm{Y}_{\mathrm{i}}\right] \mathrm{u}}\end{array}$ \\
\hline & & $\begin{array}{l}\text { Regional budgets in areas with dominant anthropogenic influence } \\
{\left[Y_{i}\right](\text { final })=\left[Y_{i} \text { (rain) }+\sum_{k=1}^{p} r_{i k}\left[P_{k}\right]+\left[Y_{i}\right] \mathrm{u}\right.}\end{array}$ \\
\hline 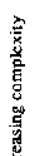 & & $\begin{array}{l}\text { Budgets of large and pristine hydrographic basins } \\
{\left[\mathrm{Y}_{\mathrm{i}}\right](\text { final })=\sum_{\mathrm{j}=1}^{m} \alpha_{\mathrm{j}}\left[\mathrm{Y}_{\mathrm{ij}}\right](\text { initial })+\sum_{\mathrm{k}=1}^{\mathrm{p}} \mathrm{r}_{\mathrm{ik}}\left[\mathrm{P}_{\mathrm{k}}\right]}\end{array}$ \\
\hline 焉 & $\begin{array}{l}\text { Budgets of small watersheds in pristine areas } \\
{\left[Y_{i}\right](\text { final })=\left[Y_{i}\right](\text { rain })+\sum_{k=1}^{p} r_{i k}\left[P_{k}\right]}\end{array}$ & \\
\hline
\end{tabular}

such as fertilizers, manures, leachates of solid waste or domestic effluents, or the development of cation exchange reactions due to the application of fertilizers on farm land. Basically, they added to the right-hand side of Equation 1 an $\left[Y_{i}\right] u$ term (where $\mathrm{u}$ means unconstrained) which gathers the contributions of all sources and chemical processes for which the user has no eapability to set valid constraints or reactions. This approach has also been employed by Pacheco et al. (1997, submitted) in a study of a granitoid and forested area with intensive agriculture and mineral waters (the Chaves-Vila Pouca area, Nortly of Portugal) with promising and mostly convincing results.

The discussion made in the previous paragraphs is summarized in Table 1 . In the future, models will certainly include both the term associated with the mixing fractions and the unconstrained term (Pacheco and Van der Weijden, in preparation), thus enabling the analysis of stream water contamination inside the boundaries of complex environments such as that existing in Morais (northern Portugal) where serpentinites, amphibolites, flaser gabbros, gneisses and micaschists outcrop within a forested area of about $400 \mathrm{~km}^{2}$ crossed by two confluent rivers (Azibo and Sabor) and occupied by two dozens of small villages.

\section{References}

Garrels, R.M. and Mackenzie, F.T. (1967) In: W. Stumm (cd.), Equilibrium concepts in natural water systems, Amer. Chem. Soc, 222-42.

Pacheco, F.A.L. and Van der Weijden, C.II. (1996) Water Resour. Res, 32, 3553-70.

Pacheco, F.A.L., Sousa Oliveira, A., Van der Weijden, A.J. and Van der Weijden, C.H., (submitted), Water, Air and Soil Pollution.

Pacheco, F.A.J., and Van der Weijden, C.H. (in preparation). Geochemical input-outpul budgets with unconstrained terms.

Parkhurst, D.L. (1997) Water Resour. Res., 33, $1957-70$.

Taylor, A.B. and Velbel, M.A. (1991) Geoderma, 51, $29-50$. 